\title{
The Importance and Side Effects of Radiotherapy For Diffuse Pigmented Villonodular Synovitis; Case Reports and Literature Review
}

\section{Diffüz Pigmente Villonodüler Sinovitte Postoperatif Radyoterapinin Önemi ve Yan Etkileri: Olgu Sunumu ve Literatür Özeti}

\author{
Gülhan Güler Avcı \\ Gaziosmanpaşa Üniversitesi Tıp Fakültesi, Radyasyon Onkolojisi Anabilim Dalı, Tokat
}

Dergiye Ulaşma Tarihi: 09.10.2019 Dergiye Kabul Tarihi: 13.01.2020 Doi: 10.5505/aot.2020.42744

\section{ÖZET}

Pigmente villonodüler sinovit (PVNS) nadir görülen, sinoviyal eklemleri/membranı tutan iyi davranışlı bir hastalıktır. En sık diz ekleminde görülür ve standart tedavisi cerrahidir. Diffüz PVNS' de tek başına cerrahi ile yüksek lokal yineleme oranları vardır. Literatürde bildirilen küçük olgu serilerine göre cerrahiye radyoterapi (RT)'nin eklenmesi ile lokal kontrol artmaktadır. Biz de bu yazıda cerrahi sonrası RT uyguladığımız iki diffüz PVNS olgusunu ve ilgili literatürü sunmaktayız. Diz ağrısı ve şişlik şikayeti ile hastanemize başvuran iki kadın olguda yapılan manyetik rezonans görüntüleme (MRG)'de diz eklemlerinde solid kitle görüntüsü izlendi. Radyolojik olarak PVNS düşünülen olgular total sinovektomiye gitti. İki diffüz PVNS olgusuna da şüpheli cerrahı sinır nedeni ile postoperatif 32 ve 36 Gy RT uyguland. Otuz bir ve 32 aylık takipte her iki olguda da lokal yineleme görülmedi. Akut yan etki gözlenmezken, bir olguda RT'nin geç komplikasyonu olarak artiküler effüzyon ve peripatellar ağrı gözlendi. Sonuç olarak RT, diffüz PVNS 'de lokal yinelemeyi önleyen ve daha ileri olgularda ekstremite koruyucu yaklaşımlara olanak sağlayan etkili ve güvenilir tedavi seçeneği olabilir.

Anahtar Kelimeler: Pigmente villonodüler sinovit, Radyoterapi, Yan etki, Sinovektomi

\begin{abstract}
Pigmented villonodular synovitis (PVNS) is a rare, well-behaved disease involving the synovial membrane and joints. Diffuse PVNS has high recurrence rate with surgery alone. We aimed to present the results and side effects of radiotherapy (RT) in two cases with PVNS in the light of literature. Two female patients were admitted to our hospital with pain and swelling on their right knees. Magnetic resonance imaging (MRI) showed a solid mass in the knee joints. Patients who were thought to have PVNS radiologically, underwent total synovectomy. Patients with diffuse PVNS received postoperative 32 and 36 Gy RT on account of uncertain surgical margin status. No acute side effects related to radiotherapy were observed in the both cases. In one case, one year after radiotherapy, the articular effusion and peripatellar pain evolved as a late complication. There were no local recurrence at 31 and 32 months follow-up. As a result, radiotherapy is a safe and effective treatment option for preventing recurrence of diffuse PVNS and provides protection of extremities in very advanced cases. However, more studies with long-term follow-up are needed.
\end{abstract}

Keywords: Pigmented villonodular synovitis (PVNS), Radiotherapy, Side Effects, Synovectomy

\section{INTRODUCTION}

Pigmented villonodular synovitis (PVNS) is a rare, well-behaved disease involving the synovial membrane and joints. The etiology of PVNS is still unknown. Some researchers argue that the disease has occurred due to recurrent trauma or immediately following hemorrhage.[1]

PVNS has 2 forms, diffuse (DPVNS) and localized (LPVNS). Although, pathologically diffuse and localized PVNS is similar, clinical presentation, prognosis and treatment are very different.[2] The standard treatment of PVNS is 
surgery. Open synovectomy, arthroscopic synovectomy or both may be performed. Recurrence of LPVNS is less likely due to total excision is possible and so it has better prognosis. DPVNS has high recurrence rate with surgery alone. In the literature, the recurrence rate of DPVNS has been reported up to $46 \%$ unless adjuvant therapy is used. [3] If there are residual diseases or suspected surgical margins, the addition of postoperative external beam radiation therapy (EBRT) increases local control.[4, 5]

In our article, we aimed to present the results and side effects of radiotherapy in two cases with PVNS in the light of literature.

\section{CASE REPORTS}

\section{Patient 1}

A 44-year-old Turkish female patient was admitted to our hospital with a complaint of pain and swelling in her right knee. We learned that the patient had a history of trauma 7 months ago. Physical examination revealed a palpable mass in the right infrapatellar lateral side. MRI showed that the synovial membrane thickened. As the surgical procedure open synovectomy was applied. Postoperative radiotherapy was considered due to uncertain surgical margin status.

Treatment plan was done using 3D planning system. Target volumes were determined with the aid of preoperative MRI. The clinical target volume (CTV) was created by including the entire synovial cavity and a $5 \mathrm{~cm}$ margin from the tumor bed to the superior-inferior directions. The planning target volume (PTV) was defined from the CTV with a margin of $7 \mathrm{~mm}$. The target volume should encompass the primary extension of the lesion together with the whole synovial lining layers of the affected joint and a adequate safety margin. [6] To accomplish a complete coverage of the affected "risk regions", a CT- and MRI-based treatment planning containing an image fusion of both imaging devices is obligatory. [6] To achieve dose homogenization, field-in-field IMRT technique was performed. A total of 36 Gy was administered in 20 fractions. Treatment plan, isodose curve, dose volume histogram (DVH) are shown in figure 1.

At the 1st month follow-up after radiotherapy, the complaint of pain decreased. No acute side effects related to radiotherapy were observed.
No recurrence was observed in 32 months follow-up.

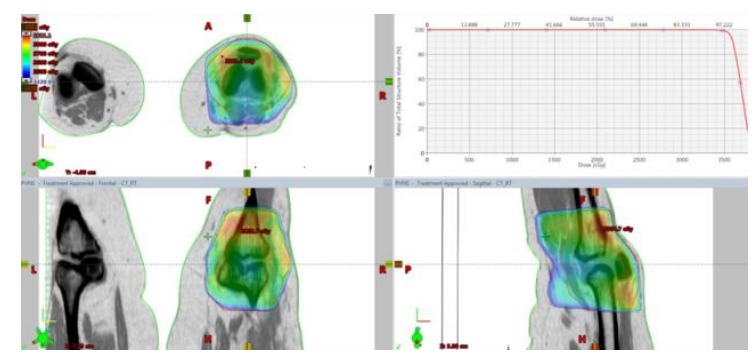

Figure 1. Planning of radiotherapy, dose-volume histogram $(\mathrm{DVH}), 95 \%$ isodose curve of patient 1

\section{Patient 2}

A 52-year-old Afghan female patient had a 2year history of pain and a locking in her right knee. The patient had no history of trauma. MRI demonstrated a 9x6x5 cm solid lesion at the suprapatellar level on lateral localization (figure 2). EBRT was applied after total synovectomy on account of diffuse PVNS and high local recurrence rates. Radiotherapy planning technique and determination of target volumes were as in previous patient. A total of $32.4 \mathrm{~Gy}$ was administered in 18 fractions.

No acute side effects related to radiotherapy were observed. One year after radiotherapy, the articular effusion and peripatellar pain developed as a late complication and puncture was performed with mini arthotomy. There was no local recurrence at 31 months follow-up.

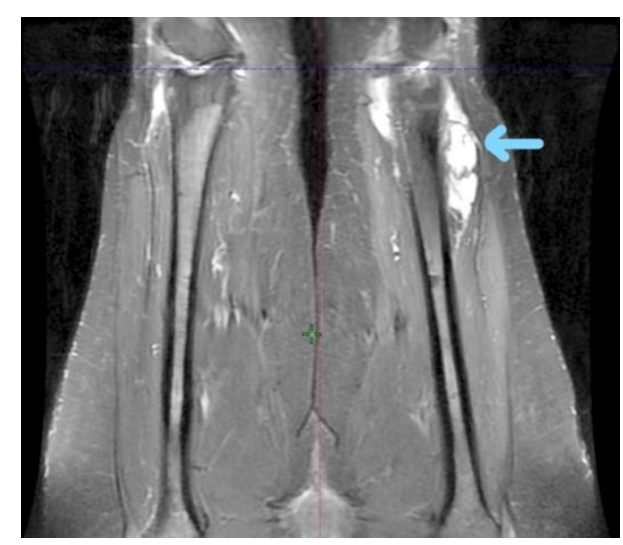




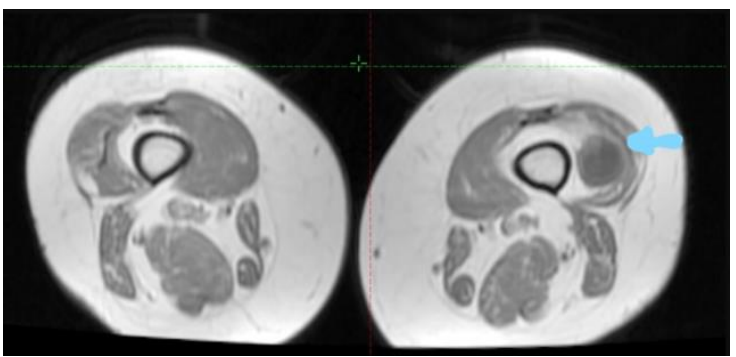

Figure 2. MRI showed a 9x6x5 $\mathrm{cm}$ solid lesion at the suprapatellar level on lateral localization, which is prominent hypointense in T1A series, heterogeneous hypointense in T2A series. (a) The Coronal Image of MRI / (b) The Axial Image of MRI of patient 2

\section{DISCUSSION}

PVNS is a chronic proliferative process that occurs in the joint, most commonly affects the knee. In the literature, recurrence rate of LPVNS was reported as $0 \%$ without any adjuvant therapy in long-term follow-up.[7] Nevertheless the high rates of recurrence in DPVNS have been reported due to the lack of sufficient synovectomy depending on arthroscopic surgery, presence of an extraarticular lesion and extensive joint involvement. If there is residual disease or uncertain margin status, postoperative EBRT can be performed, which enhances local control in patients with DPVNS. [4, 5] In our two cases, postoperative EBRT following complete synovectomy was performed because of uncertain margin status. In a single center retrospective study by $\mathrm{Li} \mathrm{W}$ et al,[8] 28 patients of DPVNS underwent arthroscopic synovectomy and postoperative RT whose dose was between $20 \mathrm{~Gy}$ and $30 \mathrm{~Gy}$. No recurrence was observed at the mean followup time, 54 months. No recurrence was observed as an advantage of RT despite arthroscopic surgery.[8]

Carvalho et al. [9] reported results of surgery followed by postoperative radiotherapy in 8 patients with PVNS. The mean dose of RT was 20 Gy (range, 10- 39.6 Gy). Only 1 patient (12\%) had recurrence at a mean follow-up of 8.6 years. In 3 cases, late minor complications such as peripatellar pain, articuler effuson and quadricipitol muscle atrophy were observed. None of the patients had any late side effects and complications.[9] In one of our cases, articular effusion and peripatellar pain developed after one year from RT as a late complication.

Horoschak et al.[5] patients with 18 sites of PVNS were treated with radiation therapy after surgery. Radiation was delivered with an average total dose 34 Gy (range, 20-36 Gy).Local control rate was $75 \%(12 / 16)$. They also argued that better local control was achieved with doses of 34-36 Gy RT.[5] In light of these studies, we administered radiotherapy to our patients with a total dose of 32-36 Gy.

\section{CONCLUSION}

Radiotherapy is a safe and effective treatment option for preventing recurrence of DPVNS and provides protection of extremities in very advanced cases. However, more studies with long-term follow-up are needed.

\section{REFERENCES}

1. Flandry F, Hughston JC, McCann SB, Kurtz DM. Diagnosticfeatures of diffuse pigmented villonodular synovitis of the knee. Clin Orthop Relat Res. 1994;(298):212-20.

2. Mollon B, Griffin AM, Ferguson PC, Wunder JS, Theodoropoulos J. Combined arthroscopic and opensynovectomy for diffuse pigmented villonodular synovitis ofthe knee. Knee Surg Sports Traumatol Arthrosc.2016;24(1):260-6.

3. Flandry F, Hughston JC. Pigmented villonodular synovitis. J Bone Joint Surg Am 1987; 69: 942-9.

4. Berger B, Ganswindt U, Bamberg M, Hehr T. External beam radiotherapy as postoperative treatment of diffuse pigmented villonodular synovitis. Int $\mathbf{J}$ Radiat Oncol Biol Phys 2007;67:1130-4.

5. Horoschak M, Tran PT, Bachireddy P, et al. External beam radiation therapy enhances local control in pigmented villonodular synovitis. Int J Radiat Oncol Biol Phys 2009;75:183-187.

6. Park G, Kim YS, Kim JH, et al. Lowdose external beam radiotherapy as a postoperative treatment for patients with diffuse pigmented villonodular synovitis of the knee: 4 recurrences in 23 patients followed for mean 9 years. Acta Orthop. 2012;83(3):256-60.

7. Auregan JC, Bohu Y, Lefevre N, et al. Primary arthroscopic synovectomy for pigmented villo-nodular synovitis of the knee: recurrence rate and functional outcomes after a mean follow-up of seven 
years. Orthop Traumatol Surg Res 2013;99:937-43.

8. Wei Li, Xiaofei Su, Jianning Lin, Wei Ji, Dike Ruan. Arthroscopic synovectomy and postoperative assisted radiotherapy for treating diffuse pigmented villonodular synovitis of the knee: An observational retrospective study, Pak J Med Sci 2015;31(4):956-960.
9. de Carvalho LH Jr, Soares LF, Gonçalves MB, Temponi EF, de Melo Silva O Jr. Long-

term success inthe treatment of diffuse pig mented villonodular synovitis ofthe knee $\mathrm{w}$ ith subtotal synovectomy and radiotherapy. Arthroscopy $2012 ; 28(9): 1271-4$. 